\title{
Two new species of megasporangiate Sigillariostrobus Schimper (Sigillariostrobaceae) fructifications from the British Coal Measures
}

\author{
B. A. Thomas ${ }^{1}$ and L. J. Seyfullah ${ }^{2}$ \\ ${ }^{1}$ Institute of Biological, Environmental and Rural Sciences, Aberystwyth University, Penglais, Aberystwyth, Ceredigion, UK \\ ${ }^{2}$ Department of Geobiology, Georg-August-Universität Göttingen, 37077 Göttingen, Germany \\ Correspondence to: L. J. Seyfullah (leyla.seyfullah@geo.uni-goettingen.de)
}

Received: 12 August 2015 - Revised: 2 November 2015 - Accepted: 3 November 2015 - Published: 16 November 2015

\begin{abstract}
The arborescent lycophyte group known as the sigillarians bore pedunculate fructifications, including Sigillariostrobus Schimper, which has a known propensity to disaggregate, making comparisons of cones and in situ spores often difficult if not impossible. Sigillariostrobus is monosporangiate, containing either megaspores or microspores. Two new species of Sigillariostrobus with megaspores are described from the British Coal Measures. Two cones of Sigillariostrobus saltwellensis sp. nov. are described from Langsettian-Duckmantian strata of Great Britain, containing in situ Laevigatisporites glabratus (Zerndt) Potonié and Kremp spores, making this the first British Sigillariostrobus species described containing such spores. Sigillariostrobus barkeri sp. nov. is given here to the previously described cone with in situ Tuberculatisporites brevispiculus (Schopf) Potonié and Kremp spores. This is the first Sigillariostrobus cone with this megaspore species in situ, and thus shows that T. brevispiculus and T. mamillarius (Bartlett) Potonié and Kremp are not conspecific as others have previously suggested.
\end{abstract}

\section{Introduction}

Sigillarian trees are one of the distinctive groups of Carboniferous arborescent lycophytes that are not as tall, or as branched, as Lepidodendron Sternberg. Arnold (1947) mentions Sigillaria reniformis to be $18 \mathrm{ft}(\mathrm{ca} .6 \mathrm{~m})$ tall and $6 \mathrm{ft}$ (ca. $2 \mathrm{~m})$ in diameter at the base, tapering to 1 foot $(30.5 \mathrm{~cm})$ at the top. This description suggests that the stem was incomplete. Balfour (1872) states that they can be $40-50 \mathrm{ft}$ (12$15 \mathrm{~m})$ tall and $5 \mathrm{ft}(\mathrm{ca} .1 .5 \mathrm{~m})$ in diameter. Balfour also gives measurements of 20 stems as $10-20 \mathrm{ft}(3-6 \mathrm{~m})$ high and 1-
$3 \mathrm{ft}(30.5 \mathrm{~cm}-1 \mathrm{~m})$ in diameter, standing erect in alternating strata of shales and sandstones, near Morpeth in Northumberland (UK). They bear cones (fructifications) on peduncles off the main stem or branches. The first figures of a fructification belonging to Sigillaria Brongniart were given by Goldenberg (1855, pl. 4, Fig. 3; 1857, pl. 10, Figs. 1, 2), but he gave no name to them. Schimper (1870, pl. 47, Figs. 1214) refigured some of Goldenberg's illustrations and gave them the name Sigillariostrobus but did not propose a holotype. Andrews (1970) included Sigillariostrobus (Schimper) Geinitz 1873 in the index that he published because the first specific name $S$. bifidus was given by Geinitz. However, Seward (1910) and Chaloner (1967) believed S. bifidus to be a conifer cone belonging to the genus Gomphostrobus Marion, 1890. For this reason Chaloner (1967) took S. goldenbergi of Feistmantel (1876) as the type species and gave the generic authorship as Sigillariostrobus (Schimper 1870) Feistmantel, 1876, non Geinitz. Feistmantel (1876) had merely given the specific name to specimens figured by Goldenberg (1855) and Schimper (1870), leaving it to Zeiller (1884) to give the first clear description and figure of $S$. goldenbergi. For this reason Chaloner (1967) proposed the type species authorship as Sigillariostrobus goldenbergi (Feistmantel) Zeiller, 1884. Feistmantel's other species, S. feistmanteli, was first regarded to be not a cone but a fertile zone and, therefore, is the type of Sporangiostrobus Bode - a genus which has since been synonymised with Omphalophloios White (Opluštil et al., 2010; Bek et al., 2015).

In situ spores have become an integral part of describing fructifications, e.g. Chaloner (1953), Thomas (1970), BrackHanes and Thomas (1983), Bek and Opluštil (1998, 2004), Thomas and Bek (2014). This leads onto a comparison of the in situ spores with named genera and species of dispersed 
spores and then to using this information for palaeoecological interpretations.

Although the spores of the type specimens of Sigillariostrobus (S. goldenbergi) are unknown, Sen (1958) described the spores of a specimen he identified to be $S$. goldenbergi as Laevigatisporites mamillarius. Examination of the spore contents of other species has shown the genus to be made up of monosporangiate cones that contain either megaspores or microspores. Of the megasporangiate cones, the megaspores spore walls are generally about $20-30 \mu \mathrm{m}$ with triradiate marks that are approximately half the radius of the spore. If the entire surface of the spore is smooth and usually with prominent curvaturae, it is of the type referred to the dispersed spore genus Laevigatisporites (Ibrahim) Potonié and Kremp. If the spore wall is ornamented with tubercles on the dorsal surface it would be referred to the dispersed spore genus Tuberculatisporites (Ibrahim) Potonié and Kremp. The number of dispersed megaspores species belonging to these two genera far exceeds the number of known cones, which must be partially due to the fact that most, if not all, Sigillariostrobus cones fall to pieces by losing their sporophylls and can even be reduced to a bare axis (Fig. 1).

The rarity of finding two more or less intact cones allows us here to describe a new Sigillariostrobus species from the British Coal Measures, with spores referable to the smooth-surfaced dispersed spore genus Laevigatisporites. We also give a name to another Sigillariostrobus cone from the British Coal Measures (Bolsovian) that has previously been described (Thomas, 1980) with spores referable to the tuberculate-surfaced dispersed spore genus Tuberculatisporites.

Megaspores that are trilete and circular in outline, with an originally concavo-convex shape, and having a complex exine ornamentation of tubercles, would clearly, if found isolated, be included within the genus Tuberculatisporites (Ibrahim) Potonié and Kremp (1954).

There are two species of Tuberculatisporites that concern us in this study: T. mamillarius (Bartlet) Potonié and Kremp (1955) and T. brevispiculus (Schopf) Potonié and Kremp (1955). Some authors, including Zerndt (1932), Dijkstra (1946, 1955a, 1955b), Arnold (1950) and Winslow (1959), believed the two species to be conspecific, while Potonié and Kremp (1955), Bhardwaj (1957a, b), Arnold (1961) and Selosse (1953) kept them separate. Spinner (1964) reexamined and redefined the genus Tuberculatisporites and included a list of species in which he distinguished $T$. mamillarius from T. brevispiculus. Following Spinner (1968) the two differ in their ornamentation. The tubercles are larger in T. mamillarius, being up to $130 \mu \mathrm{m}$ tall and $94 \mu \mathrm{m}$ in basal diameter on the distal surface, with them up to $28 \mu \mathrm{m}$ tall and $25 \mu \mathrm{m}$ in basal diameter on the proximal contact faces. In $T$. brevispiculus they are only $10 \mu \mathrm{m}$ tall and vary from 25 to 30 and 40 to $45 \mu \mathrm{m}$ in basal diameter on the distal surface, while the proximal contact faces are covered in apiculi that are $15 \mu \mathrm{m}$ in diameter and less than $5 \mu \mathrm{m}$ tall.

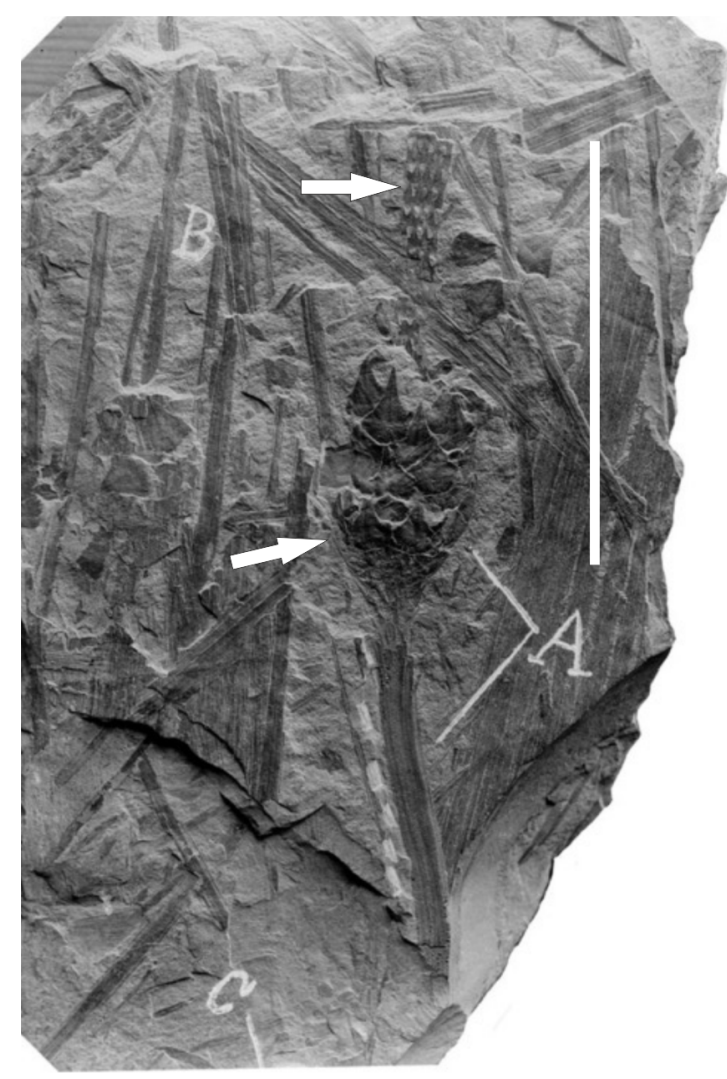

Figure 1. Sigillariostrobus fructification with only a few basal sporophylls (lower arrow), having shed most of its sporophylls exposing the upper part of the axis (upper arrow) as illustrated by Kidston (1897) (scale bar $50 \mathrm{~mm}$ ). From the Kidston Collection at the British Geological Survey. Catalogue number: P686530. Reproduced with permission of the British Geological Survey @NERC. All rights reserved.

\section{Materials and methods}

The cones were investigated using a Carl Zeiss Stemi 2000 microscope with incident light equipped with a Canon 450D digital camera. Spore preparations were made by maceration with Schulze solution and cleared using dilute (4\%) ammonia solution. The resulting spores were slide-mounted in glycerine jelly as with dispersed spores. These spore preparations were observed with a transmitted light microscope (Carl Zeiss Axioscope A1) also equipped with a Canon 450D digital camera, and will be deposited with the specimens.

There are three cones that form the basis of this paper. One cone (Pb. 53-C.203, Hunterian Museum, Glasgow) comes from the southern part of the South Staffordshire coalfield from Saltwells Pit (now part of the Saltwells National Nature Reserve). The exact horizon of the specimen is unknown, although Besley (1988) refers to the general horizon as alluvial coal-bearing facies of the upper Langsettian-Duckmantian, which represent continuously emergent conditions allowing the extensive development of swamp soils. A second cone 
( $\mathrm{Pb}$. 707, Hunterian Museum, Glasgow) has no record of where it was collected. The third specimen, no. 1971.I28 from the Barker collection, Sheffield City Museum, was collected from above the Shafton Coal, Brierley Colliery, Yorkshire - top of the Similis-Pulchra Zone (Bolsovian).

\section{Systematic descriptions}

\section{(B. A. Thomas, L. J. Seyfullah)}

\section{Family Sigillariostrobaceae Thomas and Brack-Hanes, 1984}

Genus Sigillariostrobus (Schimper 1870) Feistmantel, 1876, non Geinitz E.

Type species: Sigillariostrobus goldenbergi (Feistmantel) Zeiller, 1884

Sigillariostrobus saltwellensis sp. nov.

(Figures 2-3)

Holotype: Specimen Pb. 53-C.203, stored in the Hunterian Museum, Glasgow.

Type locality: Saltwells Pit, near Cradley Heath, Staffordshire, Great Britain.

Type stratum: Alluvial coal-bearing facies - upper Langsettian-Duckmantian.

Etymology: Named after the locality of the specimen that we designate as the type.

Diagnosis: Cone at least $86 \mathrm{~mm}$ long, ca. $17-20 \mathrm{~mm}$ in diameter, axis $1.2 \mathrm{~mm}$, pedicel ca. $8 \mathrm{~mm}$ long, sporangia $7 \mathrm{~mm}$ long, sporophyll laminae 12 broad at base, $6.3 \mathrm{~mm}$ long spreading outwards from the cone. Sporangia $7 \mathrm{~mm}$ long, $2.5 \mathrm{~mm}$ high. Megaspores trilete, probably originally plano-convex, average diameter $2000 \mu \mathrm{m}$ in their equatorial planes, smooth walls with a thickened area between the arms of the trilete mark. Lesurae approximately half the spore radius, ca. $15 \mu \mathrm{m}$ broad at the centre of the spore.

Description: Both cones are preserved as dark compression (Figs. 2a-b, 3a-b), although they are broken somewhere above their bases (Figs. 2a, c, 3a, c), so their complete length is unknown. The megasporophylls have free tips approximately $6.3 \mathrm{~mm}$ long (Fig. 3d), only slightly diverging from the sides of the cone. The megasporophylls are not well preserved (Figs. 2b-c, 3d) and the compression material is very brittle, so the cuticle could not be prepared. Numerous obvious large red-brown megaspores are visible to the naked eye (Figs. 2d, 3e). They all measure approximately $2000 \mu \mathrm{m}$ in diameter in their equatorial plane, with lesurae $50 \mu \mathrm{m}$ long. The entire surfaces of the spores are smooth (Figs. 2e, $3 f)$.

Comments: A second specimen, $\mathrm{Pb}$. 707, also stored in the Hunterian Museum, Glasgow, is referred to this species, but the locality and horizon information for this specimen is not known.

Discussion: The megaspores clearly fit within the parameters of the dispersed spore genus Laevigatisporites and are closest to the species L. glabratus (Zerndt) Potonié and Kremp, 1956. We agree with Karczewska (1967) that the spores described by Zerndt (1930) as Types 9 and 10 should be referred to Laevigatisporites glabratus as a result of Bochenski's (1936) description of the spores from his Sigillariostrobus czarnockii. Bochenski (1936) described the spores as 440 to $2700 \mu \mathrm{m}$ in diameter, and underdeveloped spores which were triangular, thicker than the normal ones and with strongly marked lesurae. Zerndt (1932) agreed that Bochenski's finding of his megaspores of Types 9 and 10 (Zerndt, 1930) in the same cone was considerably important to the understanding of Triletes glabratus (now Laevigatisporites glabratus).

We also agree that there are no reliable grounds to distinguish such species as Laevigatisporites primus Wicher and Laevigatisporites reinschi Ibrahim, as has been done by Potonié and Kremp (1955). Erecting the species Sporites primus, Wicher (1934) assigned only the specific name to the spores, described by Bennie and Kidston (1886) and Zerndt (1930) as Triletes Type I Kidston. Wicher (1934) interpreted the species Sporonites reinschi Ibrahim to be identical to Sporites primus; he erected himself and - contrary to the law of priority - included Sporonites reinschi Ibrahim in the synonymy of $S$. primus Wicher. After the publication of Bochenski's work, it became clear that the spores of Triletes Type I Kidston $(=$ Sporonites reinschi $=$ Sporites primus $)$ and Triletes glabratus Zerndt belong to the same species. Triletes glabratus Zerndt, 1930, is the oldest specific name and, therefore, has specific priority.

In situ spores identified as being identical to Laevigatisporites glabratus (Zerndt) Potonié and Kremp have been also described from four species of Sigillariostrobus. They are S. tieghemi Zeiller, 1884 (Schenk 1885, Zeiller 1888), S. quadrangularis (Lesquereux) White, 1903 (Wood, 1957), S. czarnockii Bochenski, 1936, and S. leiosporous Abbott, 1963. The features of these cones together with those of the British cones are summarised in Table 1.

Both S. czarnockii and S. leiosporous have sporophyll laminae with ciliate edges, which is a feature not observed in the cones from localities in Britain. S. quadrangularis has its sporophylls in whorls, which is a most unusual character for Sigillariostrobus. This again is different from the helical arrangement in the cones from localities in Britain. S. tieghemi is described as having downward-projecting heels at the distal end of the pedicel, a feature which is again not shown by the cones from localities in Britain. Although all these cones contain megaspores that would be included in the same dispersed spore species, Laevigatisporites glabratus, there are characters of the cones which lead us to the conclusion that they are all different in some respects. For that reason we ac- 

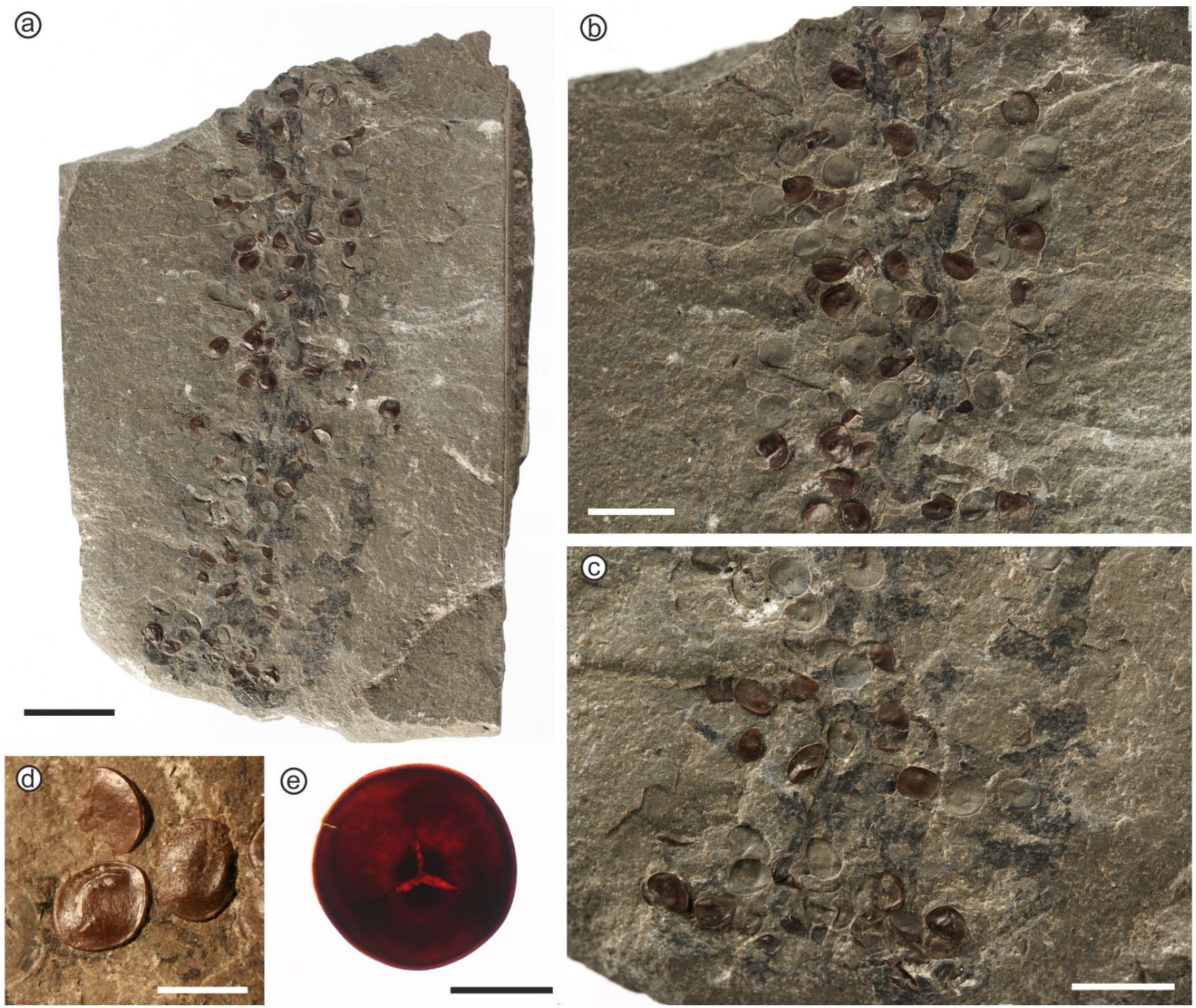

Figure 2. Type specimen of Sigillariostrobus saltwellensis sp. nov. Specimen Pb. 53-C.203, Hunterian Museum, Glasgow. Alluvial coalbearing facies - upper Langsettian-Duckmantian. (a) Cone (scale bar $10 \mathrm{~mm}$ ). (b) Detail of apical portion of the cone (scale bar $5 \mathrm{~mm}$ ). (c) Detail of basal portion of the cone (scale bar $5 \mathrm{~mm}$ ). (d) In situ glabrous megaspores (scale bar $2 \mathrm{~mm}$ ). (e) Spore referable to Laevigatisporites glabratus macerated from the cone (scale bar $1000 \mu \mathrm{m})$.

cept them all as distinct species and therefore refer the British specimens to a new species.

The anatomically preserved monosporangiate Mazocarpon Benson, 1918 includes two species that contain spores referable to Laevigatisporites glabratus. They are M. oedipterum Schopf, from the McLeansboro Group, in Illinois (Schopf, 1941, late Pennsylvanian (Stephanian A)), and $M$. bensonii Pigg, from the Duquesne Coal, Conemaugh Group, Ohio (late Pennsylvanian (Stephanian B)). Pigg (1983) showed the two species to have sufficiently different anatomical features to be separated. Although it is almost certain that Sigillariostrobus and Mazocarpon represent the same type of sigillarian cone but are merely preserved differently, we hesitate to include our $S$. saltwellensis within either of these two species because of the lack of anatomical evidence and their rather different ages.

\section{Sigillariostrobus barkeri sp. nov}

(Figure 4)

Holotype: Specimen number 1971.I28 held in the Barker collection, Sheffield City Museum.

Type locality: Brierly Colliery, Yorkshire, Great Britain.

Type horizon: Shale above the Shafton Coal, top of the Similis-Pulchra Zone, Bolsovian.

Etymology: Named after the collection where the speci- 
Table 1. Morphological comparison of Sigillariostrobus cones with in situ spores referable to Laevigatisporites glabratus.

\begin{tabular}{|c|c|c|c|c|c|}
\hline & $\begin{array}{l}\text { S. tieghemi } \\
\text { Zeiller, } 1884\end{array}$ & $\begin{array}{l}\text { S. quadrangularis (Les- } \\
\text { quereux) White, } 1903\end{array}$ & $\begin{array}{l}\text { S. czarnockii Bochen- } \\
\text { ski, } 1936\end{array}$ & $\begin{array}{l}\text { S. leiosporous Abbott, } \\
1963\end{array}$ & $\begin{array}{l}\text { Sigillariostrobus } \\
\text { saltwellensis sp. } \\
\text { nov. }\end{array}$ \\
\hline Cone size & $\begin{array}{l}160 \mathrm{~mm} \text { long } \\
25-50 \mathrm{~mm} \\
\text { broad }\end{array}$ & $\begin{array}{l}\text { Up to } 160 \mathrm{~mm} \text { long, av- } \\
\text { erage width } 11.6 \mathrm{~mm}\end{array}$ & $\begin{array}{l}\text { ca. } 180 \mathrm{~mm} \text { long, } 17- \\
25 \mathrm{~mm} \text { broad }\end{array}$ & $\begin{array}{l}\text { Up to } 180 \mathrm{~mm} \text { long, } \\
20 \mathrm{~mm} \text { broad }\end{array}$ & $\begin{array}{l}\text { At least } 86 \mathrm{~mm} \\
\text { long, } 17-20 \mathrm{~mm} \\
\text { broad }\end{array}$ \\
\hline Cone axis & & $1 \mathrm{~mm}$ & $7-8 \mathrm{~mm}$ & $4-7 \mathrm{~mm}$ & $1.2 \mathrm{~mm}$ \\
\hline $\begin{array}{l}\text { Sporophyll } \\
\text { arrangement }\end{array}$ & $\begin{array}{l}\text { Alternating } \\
\text { whorls with } \\
8-10 \text { per whorl }\end{array}$ & In whorls & $\begin{array}{l}\text { Helical with sporo- } \\
\text { phylls lying above one } \\
\text { another }\end{array}$ & $\begin{array}{l}\text { Alternating verticils } \\
\text { of } 4-5 \text { sporophylls; } \\
3-4 \text { mm between } \\
\text { verticils }\end{array}$ & Helical \\
\hline $\begin{array}{l}\text { Sporophyll } \\
\text { shape }\end{array}$ & $\begin{array}{l}\text { With prominent } \\
\text { heel }\end{array}$ & $\begin{array}{l}\text { Sporophyll laminae } \\
9 \mathrm{~mm} \text { long }\end{array}$ & $\begin{array}{l}\text { Sporophylls } 20-25 \mathrm{~mm} \\
\text { long; upper part } \\
\text { sharply pointed with a } \\
\text { hollowed-out deltoid } \\
\text { shape, margin ciliate. }\end{array}$ & $\begin{array}{l}\text { Pedicels: } 5-7 \mathrm{~mm} \text { long, } \\
1 \mathrm{~mm} \text { broad at attach- } \\
\text { ment point, widening to } \\
4 \mathrm{~mm} \\
\text { Laminae: broadly } \\
\text { triangular, acuminate, } \\
5-8 \mathrm{~mm} \text { long, } 4-6 \mathrm{~mm} \\
\text { broad, margin ciliate }\end{array}$ & $\begin{array}{l}\text { Laminae ca. } \\
6.5 \mathrm{~mm} \text { long, } \\
\text { spreading out- } \\
\text { wards from } \\
\text { cone }\end{array}$ \\
\hline Sporangia & None observed & $\begin{array}{l}4 \mathrm{~mm} \text { long, } 5 \mathrm{~mm} \text { high, } \\
4 \mathrm{~mm} \text { broad }\end{array}$ & $\begin{array}{l}4-7 \mathrm{~mm} \text { long, breadth } \\
2-4.5 \mathrm{~mm} \text {; } \\
\text { contain three tetrads of } \\
\text { megaspores }\end{array}$ & $\begin{array}{l}4-5 \mathrm{~mm} \text { long, } 2 \mathrm{~mm} \\
\text { high, } 4-4.5 \mathrm{~mm} \text { wide; } \\
\text { contains one tetrad of } \\
\text { megaspores }\end{array}$ & $\begin{array}{l}7 \mathrm{~mm} \text { long, } \\
2.5 \mathrm{~mm} \text { high }\end{array}$ \\
\hline Peduncle & $\begin{array}{l}\text { Acicular leaves } \\
\text { or bracts } \\
\text { attached to the } \\
\text { upper portion }\end{array}$ & None observed & $\begin{array}{l}\text { At least } 40 \mathrm{~mm} \text { long } \\
\text { and } 7-8 \mathrm{~mm} \text { broad, } \\
\text { uppermost } 30 \mathrm{~mm} \text { with } \\
\text { long, triangular and } \\
\text { pointed sterile leaves } \\
25 \mathrm{~mm} \text { long and } 25 \mathrm{~mm} \\
\text { wide at the base }\end{array}$ & $\begin{array}{l}\text { At least } 65 \mathrm{~mm} \text { long } \\
\text { and } 2-5 \mathrm{~mm} \text { broad, } \\
\text { covered with minute } \\
\text { stiff spines up to } 1 \mathrm{~mm} \\
\text { long }\end{array}$ & None observed \\
\hline $\begin{array}{l}\text { Age and } \\
\text { locality }\end{array}$ & $\begin{array}{l}\text { Age unknown, } \\
\text { Valenciennes, } \\
\text { France }\end{array}$ & $\begin{array}{l}\text { Brazil Formation, } \\
\text { Upper Pottsville, } \\
\text { Duckmantian/ } \\
\text { Bolsovian } \\
\text { Indiana, USA }\end{array}$ & $\begin{array}{l}\text { Duckmantian, Upper } \\
\text { Silesian Basin, Poland }\end{array}$ & $\begin{array}{l}\text { Upper Freeport (no. } \\
\text { 7) Coal Allegheny, } \\
\text { mid-Pennsylvanian, } \\
\text { Bolsovian/Asturian, } \\
\text { southeastern Ohio, } \\
\text { USA }\end{array}$ & $\begin{array}{l}\text { Upper Langsettian- } \\
\text { Duckmantian }\end{array}$ \\
\hline
\end{tabular}

men had been deposited, the Barker collection held at the Sheffield Museum, Great Britain.

Diagnosis: Cone at least $13 \mathrm{~mm}$ in diameter without sporophyll laminae; axis $3 \mathrm{~mm}$ in diameter. Sporangia ca. $5.5 \mathrm{~mm}$ long and $2 \mathrm{~mm}$ high, megasporangiate. Megaspores trilete, probably originally plano-convex with greatest diameters of $1400-1800 \mu \mathrm{m}$ in their equatorial planes. Lesurae one-third to one-half the spore radius, ca. $15 \mu \mathrm{m}$ broad. Spore walls are about $20 \mu \mathrm{m}$ thick, covered with numerous conical apiculi. Apiculi on distal walls ca. $10 \mu \mathrm{m}$ high, varying in basal diameter and in numbers from 300 apiculi, $40-45 \mu \mathrm{m}$ broad at the base, to 550 apiculi, $25-30 \mu \mathrm{m}$ broad at the base. Apiculi on the contact faces are about $15 \mu \mathrm{m}$ broad at the base and less than $5 \mu \mathrm{m}$ high.

Description: The specimen is a fragment of a cone with lit- tle remaining except the megaspores arranged in the positions they must have occupied in the sporangia (Fig. 4ab). This is a single Sigillariostrobus cone $13 \mathrm{~mm}$ in diameter that lacks sporophyll laminae (Fig. 4a), with an axis $3 \mathrm{~mm}$ in diameter. The sporangial remains are ca. $5.5 \mathrm{~mm}$ long and $2 \mathrm{~mm}$ high, containing in situ spores, referable to the dispersed spore genus Tuberculatisporites (Ibrahim) Potonié and Kremp. Megaspores recovered from the specimen have a maximum diameter of $1400-1800 \mu \mathrm{m}$ in their equatorial planes, with lesurae one-third to one-half of the spore radius, and are clearly trilete (Fig. 4c) and tuberculate (Fig. 4d). The spore walls are about $20 \mu \mathrm{m}$ thick and are covered with numerous conical apiculi (Fig. 4d-e). The size and distribution of the apiculi vary over the surface of the megaspores, with the apiculi on the contact faces being smaller than those elsewhere on the surface. On the distal walls of the megaspores, 
(a)
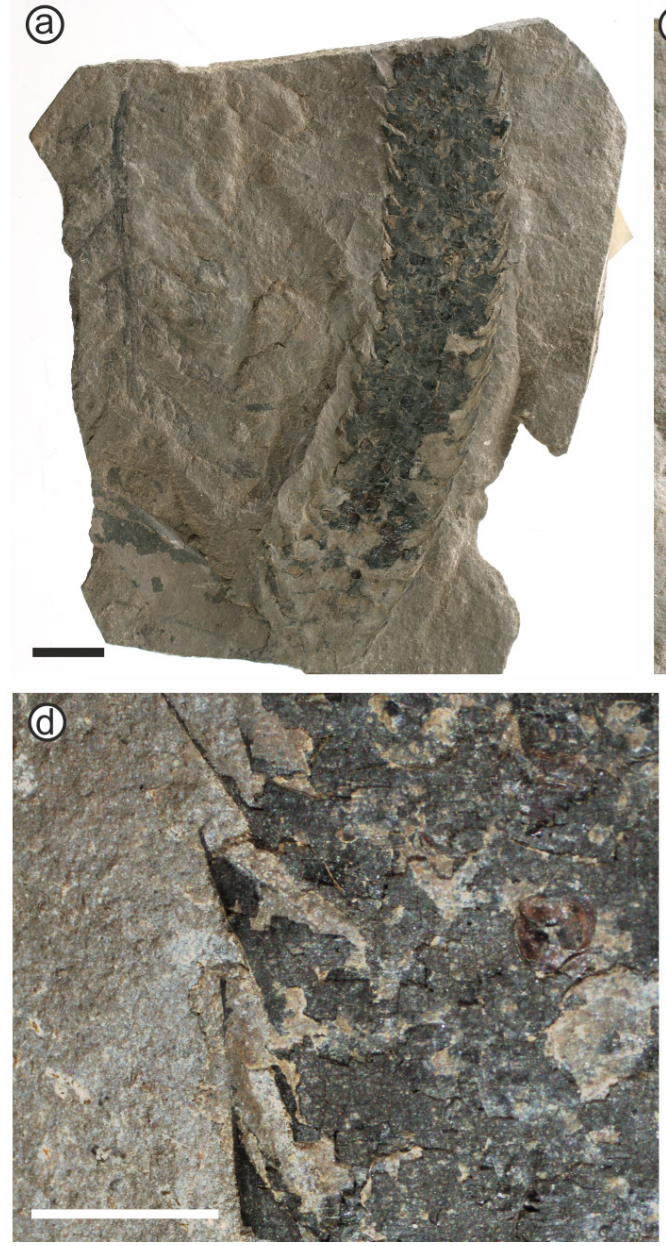
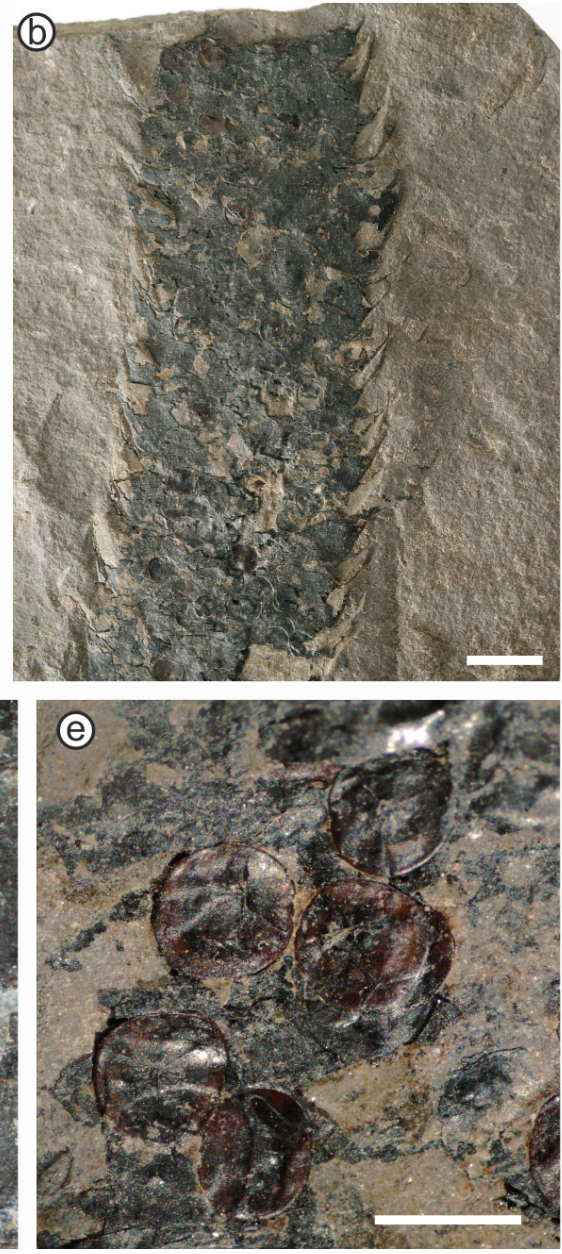

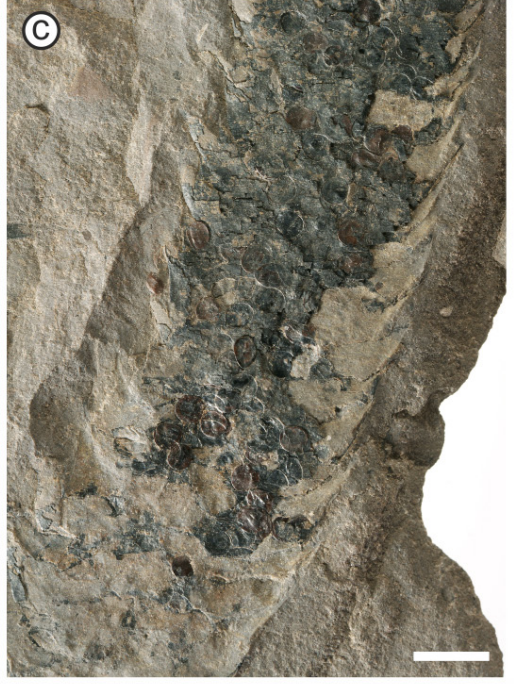

(f)

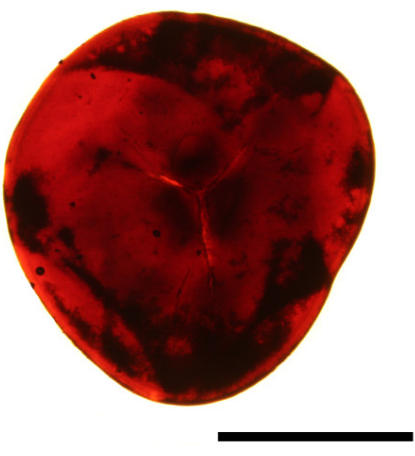

Figure 3. Second cone of Sigillariostrobus saltwellensis sp. nov. Specimen Pb. 707, Hunterian Museum, Glasgow. (a) The cone (scale bar $20 \mathrm{~mm}$ ). (b) Detail of the upper part of the cone (scale bar $5 \mathrm{~mm}$ ). (c) Detail of the mid-region of the cone, showing the megasporophyll impressions at the edge of the cone, often without the cuticle preserved (scale bar $5 \mathrm{~mm}$ ). (d) Detail of (c), showing the megasporophylls with fissile compression and scattered megaspores (scale bar $5 \mathrm{~mm}$ ). (e) Detail of (d), showing details of megaspores within the cone (scale bar $2 \mathrm{~mm}$ ). (f) Megaspore referable to Laevigatisporites glabratus macerated from the spore mass shown in (e) (scale bar $2000 \mu \mathrm{m})$.

the apiculi are ca. $10 \mu \mathrm{m}$ high, varying in basal diameter and in numbers from 300 apiculi, $40-45 \mu \mathrm{m}$ broad at the base to 550 apiculi, $25-30 \mu \mathrm{m}$ broad at the base. On the contact faces of the megaspores, the apiculi are about $15 \mu \mathrm{m}$ broad at the base and less than $5 \mu \mathrm{m}$ high.

Discussion: This Sigillariostrobus cone was originally described by Thomas (1980: Figs. 3-6). Although the megaspores were closely compared with Tuberculatisporites brevispiculus (Schopf) Potonié and Kremp, which was the first record of this spore, the cone was not given a specific name. Spores belonging to the genus Tuberculatisporites, like those referred to the smooth-walled Laevigatisporites (Zerndt) Potonié and Kremp (1954), have been recovered several times from sigillarian cones but from no others. Spores referable to Tuberculatisporites mamillarius have been previously described from Sigillariostrobus rhombibracteatus by Bochenski (1936), Chaloner (1953) and Wood (1957), but this is the only record of in situ spores referable to T. brevispiculus. As explained above, Tuberculatisporites brevispiculus has been discussed many times in relation to its possible affinity with T. mamillarius (Bartlett) Potonié and Kremp (1955). We are following Spinner (1968), who kept them separate. As Thomas (1980) regarded the present cone as sigillarian and referred it to Sigillariostrobus, we now consider that it would be preferable to make it the basis of a new species.

The age of the new cone is also of some importance since Spinner (1968) gives the stratigraphical range of T. brevispiculus as generally Asturian and early Stephanian. In contrast, T. mamillarius and Sigillariostrobus rhombibracteatus have been only described from the Langsettian and Duckmantian. The present cone, in coming from the early Bolsovian, seems to fall between the two zones mentioned by Spinner (1968). Nevertheless, no real problem is posed by this new record as this extended stratigraphical 


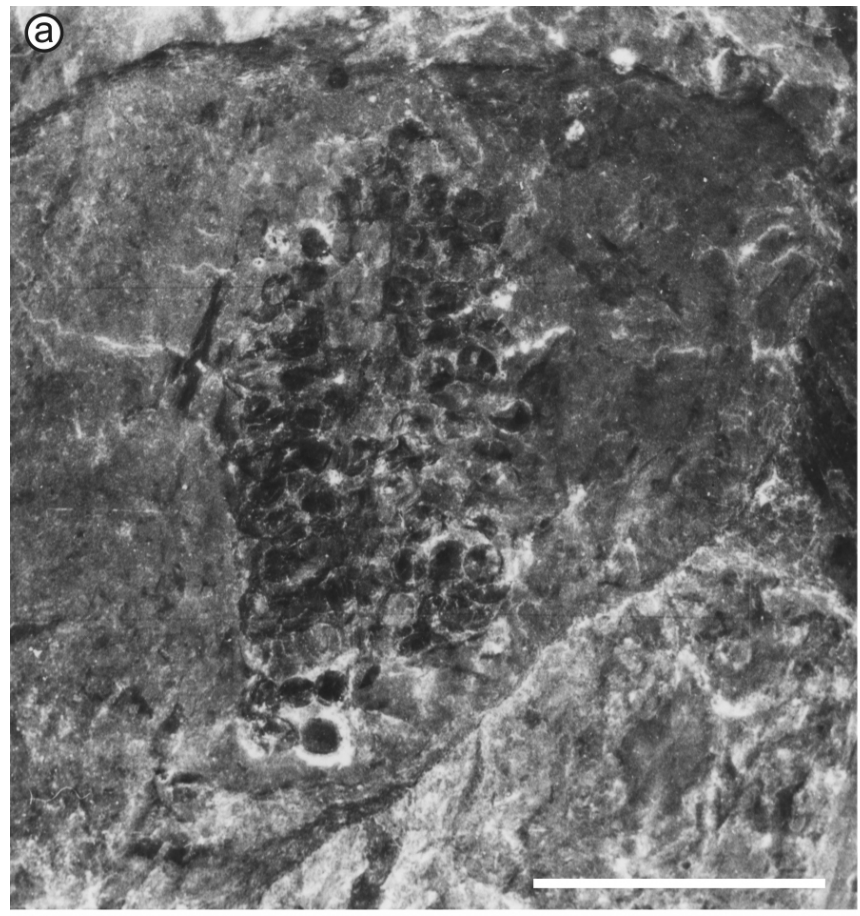

(b)
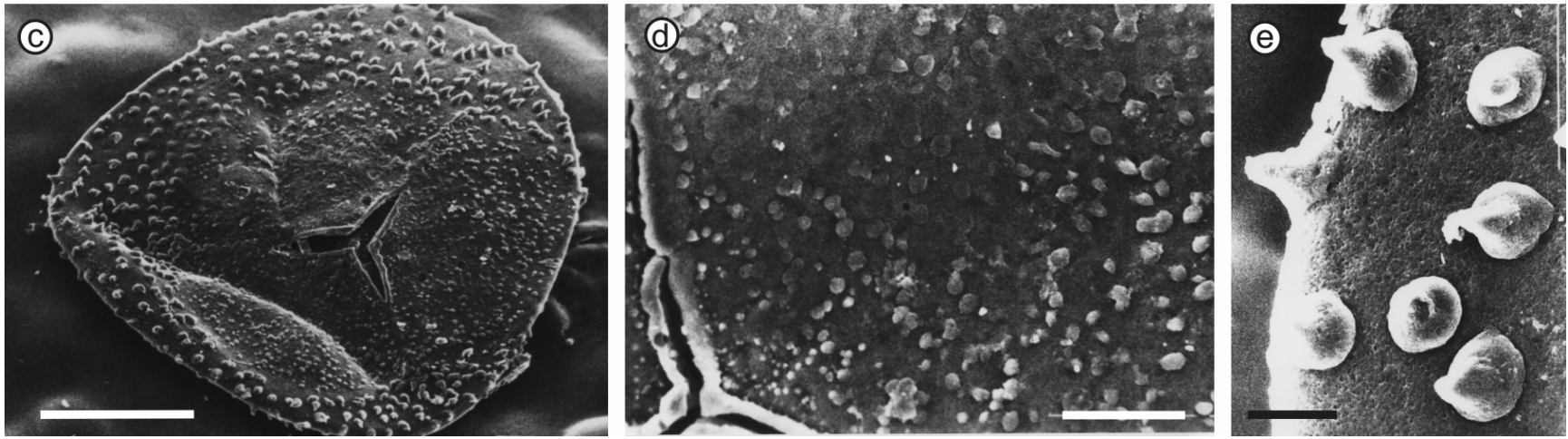

Figure 4. Sigillariostrobus barkeri sp. nov. No. 1971.I28, Barker collection, Sheffield City Museum, from the shales above the Shafton Coal, Brierly Colliery, Yorkshire (top of the Similis-Pulchra Zone, Bolsovian, Moscovian). (a) The remains of the cone showing the arrangement of the megaspores (scale bar $10 \mathrm{~mm}$ ). (b) Camera lucida drawing of the cone in (a) (scale bar $10 \mathrm{~mm}$ ). (c) Macerated in situ megaspore assigned to Tuberculatisporites mamillarius (Bartlett) Potonié and Kremp (scale bar $500 \mu \mathrm{m}$ ). (d) Contact face of the in situ megaspore (scale bar $150 \mu \mathrm{m})$. (e) Apiculi on the distal surface of the in situ megaspore (scale bar $10 \mu \mathrm{m})$. Figure previously published by Thomas (1980).

range of T. brevispiculus still does not overlap with the range of T. mamillarius.

\section{Conclusions}

Despite the tendency of the sigillarian fructification Sigillariostrobus to fall apart, two cones of Sigillariostrobus saltwellensis sp. nov. are described from the British upper Langsettian-Duckmantian strata, containing spores referable to the dispersed spore species Laevigatisporites glabratus, and these have been compared to the four other Sigillariostrobus cones that contain L. glabratus spores. This is also the first Sigillariostrobus cone species described containing L. glabratus spores from localities in Great Britain.

Sigillariostrobus barkeri sp. nov. of Bolsovian age is given to the previously described but unnamed cone with in situ spores referable to T. brevispiculus. This is the first cone with this megaspore species in situ, and thus shows that $T$. brevispiculus and T. mamillarius are not conspecific.

Author contributions. B. A. Thomas and L. J. Seyfullah prepared the specimens, made the descriptions and comparisons, and prepared the manuscript together. 
Acknowledgements. We thank the Hunterian Museum for the opportunity to examine their specimens, and also both Jiři Bek and Stanislav Opluštil for their helpful comments on the manuscript. We gratefully acknowledge support by the German Research Foundation and the Open Access Publication Funds of the Göttingen University. L. J. Seyfullah thanks the University of Göttingen for their continuing support.

Edited by: D. Korn

Reviewed by: J. Bek and S. Opluštil

\section{References}

Abbot, M. L.: Lycopod fructifications from the Upper Freeport (No. 7) coal in southeastern Ohio. Palaeontogr. Abt. B., 112, 93-118, 1963.

Andrews, H. N.: Index of Generic Names of Fossil Plants 18201965, Geological Survey Bulletin, 1300, Washington, 1970.

Arnold, C. A.: An introduction to paleobotany, McGraw-Hill, New York and London, 1947.

Arnold, C. A.: Megaspores from the Michigan Coal Basin. Contrib. Mus. Paleontol. Univ. Michigan, 8, 59-111, 1950.

Arnold, C. A.: Re-examination of Triletes superbus, T. rotatus and T. mamillarius of Bartlett. Brittonia, 3, 245-252, 1961.

Balfour, J. H.: Introduction to the study of palaeontological botany, Adam \& Charles Black, Edinburgh, 1872.

Bek, J. and Opluštil, S.: Some lycopsid, sphenopsid and pteropsid fructifications and their miospores from the Upper Carboniferous of the Bohemian Massif, Palaeontogr, Abt. B., 248, 127-161, 1998.

Bek, J. and Opluštil, S.: Six rare Lepidostrobus cones from the Pennsylvanian of the Czech Republic and their bearing on the classification of lycospores, Rev. Palaeobot. Palyno., 131, 49-89, 2004.

Bek, J., Opluštil, S., Drábková, J., and Pšenička, J.: The subarborescent lycopsid Omphalophloios feistmantelii (O. Feistmantel) comb. nov. emend. from the Middle Pennsylvanian of the Czech Republic, Bull. Geosci., 90, 227-279, 2015.

Bennie, J. and Kidston, R.: On the occurrence of spores in the Carboniferous formation of Scotland, Proceedings of the Royal Physical Society of Edinburgh, 9, 82-117, 1886.

Benson, M.: Mazocarpon or the structure of Sigillariostrobus, Ann. Bot., 32, 569-589, 1918.

Besley, B.: Palaeogeographical implications of late Westphalian to early Permian red-beds, central England, in: Sedimentation in a Synorogenic Basin Complex. The Upper Carboniferous of Northwest Europe, edited by: Besley, B. M. and Kelling, G., Blackie, Glasgow, 1988.

Bhardwaj, D.: The Palynological Investigations of the Saar coals (part 1 - Morphology of Sporae dispersae, Palaeontogr. Abt. B., 101, 72-125, 1957a.

Bhardwaj, D.: The spore flora of Velener Schicten (lower Westphalian D) in the Ruhr Coal Measures, Palaeontogr. Abt. B., 102, 110-138, 1957b.

Bochenski, T. A.: Über sporophyllstände [Blütem] einige Lepidophyten aus dem produktiven Karbon Polens, Jargang XII (1936) der Polischen Geologischen Gesellschaft, 193-240, 1936.
Brack-Hanes, S. D. and Thomas, B. A.: A re-examination of Lepidostrobus Brongniart. Bot. J. Linn. Soc., 86, 125-133, 1983.

Chaloner, W. G.: On the megaspores of Sigillaria, Ann. Mag. Nat. Hist. Ser., 12, 881-897, 1953.

Chaloner, W. G.: Lycophyta. In Boureau, Ed. Traité de Paléobotanique II, 437-845, 1967.

Dijkstra, S. J.: Eine monographische Bearbeitung der Karbonischen Megasporen, Meded. Geol. Stitchting, 111-1, 1-101, 1946.

Dijkstra, S. J.: The megaspores of the Westphalian D and C. Meded. Geol. Stichting, serie 3, 8, 5-11, 1955a.

Dijkstra, S. J.: La Corrèlation des veines de Charbon par les mégaspores, Publ. Ass. Etud. Paléont, 21, 107-119, 1955 b.

Feistmantel, O.: Die Versteinerungen der böhmischen Ablagerungen III, Palaeontographica, 23, 223-231, 1876.

Goldenberg, F.: Flora Sarapontana Fossilis. Die Pflanzenversteinerungen des Steinkohlengebirges von Saarbrücken I, 1-35 Saarbrücken, 1855.

Goldenberg, F.: Flora Sarapontana Fossilis. Die Pflanzenversteinerungen des Steinkohlengebirges von Saarbrücken II, 1-19, Saarbrücken, 1857.

Ibrahim, A. C.: Sporenformen aus den Flözen Ägir und Bismarck des Ruhrgebietes, in: Neues Jahrbuch für Mineralogie, edited by: Potonié, R., Beil.-Bd.67, Abt. B, 438-454, Stuttgart, 1932.

Karczewska, J.: Carboniferous spores from the Chelm I boring (Eastern Poland), Acta Palaeontol. Pol., 12, 267-345, 12 Taf, 1967.

Kidston, R.: On the fossil flora of the Yorkshire Coal field. II. Trans. Roy. Soc. Edinburgh, 39, 33-62, pls 1-3, 1897.

Marion, A. F.: Sur le Gomphostgrobus heterophylla, conifère prototypique du Permien de Lodeve, Academie du Science Paris, Comptes Rendus, 110, 892-894, 1890.

Opluštil, S., Bek, J., and Schultka, S.: Re-examination of the genus Omphalophloios White, 1898 from the Upper Silesian Coal Basin, Bull. Geosci., 85, 39-52, 2010.

Pigg, K. B.: The morphology and reproductive biology of the Sigillarian cone Mazocarpon, Bot. Gaz., 144, 600-613, 1983.

Potonié, R. and Kremp, G.: Die Gattungen der pälaozoischen Sporae dispersae und ihre Stratigraphie, Geol. Jb., 69, 111-194, 1954.

Potonié, R. and Kremp, G.: Die Sporae dispersae des Ruhrkarbons, ihre morphographie und stratigraphie mit ausblicken auf arten anderer gebiete und zeitabschnitte, Palaeontogr. Abt. B., 98, 1136, 1955.

Schenk, A.: Über Sigillariostrobus. Abdruck a. d. Berichte d. math.-phys. Classeb d. Königl, Sächsischen Gesellschaft. d. Wissenschaften zu Leipzig. Ber. 37, S127-131, 1885.

Schimper, W. P.: Traité de Paléontologie Végétale, ou la Flore du Monde Primitif, Vol. II, 1-522, pls 57-84, 1870.

Schopf, J. M.: Contributions to Pennsylvanian paleobotany $M a-$ zocarpon oedipterum, sp. nov, and sigillarian relationships, Ill. State Geo. Surv. Rep. Invest., 75, 1-53, 1941.

Selosse, N.: Inventaire des Megaspores du Faisceau de Meunière (Westphalian B. Inf.) dans la Bassin houiller du Nord du Pas-deCalais, Ann. Soc. Géol. Nord, 83, 61-69, 1953.

Sen, J.: Notes on the spores of four Carboniferous Lycopods, Micropaleontology, 4, 159-164, 1958.

Seward, A. C.: Fossil Plants. Vo. II, 1-624, 1910. 
Spinner, E.: Contribution on the megaspore genus Tuberculatisporites (Ibrahim) Potonié and Kremp 1954, Pollen et Spores, 10, 395-410, 1968.

Thomas, B. A.: A new specimen of Lepidostrobus binneyanus from the Westphalian B of Yorkshire, Pollen et Spores, 12, 217-234, 1970.

Thomas, B. A.: Notes on Bothrodendron depereti Vaffier and a Sigillariostrobus with Tuberculatisporites brevispiculus megaspores, Argumenta Palaeobotanica, 6, 157-164, 1980.

Thomas, B. A. and Bek, J.: A reassessment of the Pennsylvanian lycophyte cone Triplosporite Brown, Acta Geol. Pol., 64, 139$145,2014$.

White, D.: Stratigraphy and paleontology of the Upper Carboniferous rocks of the Kansas Section, Department of the Interior, U.S. Geological Survey Bulletin 211, Ser. C, Systematic Geology: Paleontology, 6, 1-106, 1903.

Wicher, C. A.: Sporenformen der Flammkohle des Ruhrgebietes, Arbeit. Instit. Paläobot. Petrograph. Brennsteine, 4, 165-212, 1934.
Winslow, M. R.: Upper Mississippian and Pennsylvanian megaspores and other plant microfossils from Illinois, Bulletin of the Illinois State Geological Survey, 86, 7-13, 1959.

Wood, J. M.: The morphology and relationships of sigillarian fructifications from the Lower Pennsylvanian of Indiana, Am. Mid. Nat., 58, 141-154, 1957.

Zeiller, R.: Cônes de fructifications de Sigillaires, Ann. Sci. nat. Bot., 19, 256-280, pls 11-12, 1884.

Zeiller, R.: Bassin houiller de Valenciennes. Description de la flore fossile, Text 1888, Atlas 1886, Étude des gîtes minéraux de France, Paris, 1886-1888.

Zerndt, J.: Megasporen aus einem Flöz in Libiaz (Stéphanien). Akademie Polonaise des Sciences Bulletin International, ser. BI, 39-70, 1930

Zerndt, J.: Megasporen aus dem Zwikauer und Lugau-Ölsnitzer Karbon, Jahrbuch Berg- und Hüttenwesen in Sachsen 1932, 10 16,1932 